\title{
KEPATUHAN PENGOBATAN ANTIRETROVIRAL PADA PASIEN HIV/AIDS DI RSUD Prof. Dr. MARGONO SOEKARJO PURWOKERTO
}

\author{
ANTIRETROVIRAL THERAPY OF HIV/AIDS PEOPLE IN Prof. \\ Dr. MARGONO SOEKARJO PURWOKERTO PUBLIC HOSPITAL
}

\author{
Githa Fungie Galistiani, Lia Mulyaningsih \\ Fakultas Farmasi Universitas Muhammadiyah Purwokerto \\ Email :githafungie@gmail.com
}

\begin{abstract}
ABSTRAK
Kepatuhan pengobatan anti retro viral pada Orang Dengan HIV/AIDS (ODHA) merupakan hal yang esensial selama pengobatan HIV/AIDS. Terapi anti retro viral dapat memperpanjang hidup ODHA, meskipun tidak dapat menyembuhkan infeksi HIV. Terapi anti retro viral dapat menekan jumlah virus di tubuh ODHA dengan pemakaian secara terus-menerus. Kelalaian meminum obat bisa menyebabkan resistensi. Oleh karena itu, kepatuhan minum obat menjadi sangat penting.Penelitian dilakukan untuk menganalisis faktor-faktor yang mempengaruhi tingkat kepatuhan terapi anti retro viral pada pasien ODHA di RSUD Prof. Dr. Margono Soekarjo Purwokerto. Instrumen penelitian yang digunakan dalam penelitian ini berupa kuesioner yang diadaptasi dari kombinasi antara AIDS Clinical Trials Group (ACTG) Adherence Questionnaire dan Morisky 8-Item Medication Adherence Questionnaire yang meliputi faktor pengetahuan, faktor keyakinan, faktor sarana, faktor jarak dan biaya, faktor dukungan sosial, faktor psikologis yang dialami pasien selama seminggu terakhir, faktor psikologis pasien yang dialami selama sebulan terakhir serta faktor efek samping obat yang dirasakan pasien. Penelitian dilakukan pada 31 pasien ODHA di RSUD Prof. Dr. Margono Soekarjo Purwokerto. Hasil uji korelasi Spearman Rank menunjukkan bahwa faktor psikologis yang dialami pasien selama seminggu terakhir $(\rho=0,408)$, faktor psikologis yang dialami pasien selama sebulan terakhir $(\rho=0,524)$ serta faktor efek samping obat $(\rho=0,449)$ yang mempengaruhi secara signifikan terhadap tingkat kepatuhan terapi anti retro viral pada pasien ODHA di RSUD Prof. Dr. Margono Soekarjo Purwokerto.
\end{abstract}

Kata kunci : tingkat kepatuhan, terapi antiretroviral, HIV/AIDS

\begin{abstract}
Anti retro viral medication adherence in people living with HIV / AIDS (ODHA) is essential for the treatment of HIV / AIDS. Anti retro viral therapy can prolong the life of people living with HIV, although it cannot cure HIV infection. Anti retro viral therapy can suppress the amount of virus in the body ODHA continously. Negligence taking drugs can lead to resistance. Therefore, medication adherence is essential. The study was conducted to analyze the adherence affecting factors of anti retro viral therapy in patients living with HIV
\end{abstract}


in Prof. Dr. Margono Soekarjo Purwokerto public hospital. The research instrument used in this study a questionnaire that was adapted from a combination of AIDS Clinical Trials Group (ACTG) Adherence Questionnaire and the 8-item Morisky Medication Adherence Questionnaire which includes factors of knowledge, confidence factors, vehicle factors, distance and cost factors, social support factors, psychological factors experienced by patients during the past week, the patient psychological factors experienced during the past month as well as the factors perceived medication side effects patients. The study was conducted on 31 patients living with HIV in Prof. Dr.Margono Soekarjo Purwokerto public hospital. Spearman Rank correlation test results showed that psychological factors experienced by patients during the last week ( $\rho$ $=0.408$ ), psychological factors experienced by patients during the past month ( $\rho$ $=0.524)$ as well as the side effects of the drug factor $(\rho=0.449)$ that significantly affect the adherence level on anti retro viral therapy of HIV/AIDS people in Prof. Dr. Margono Soekarjo Purwokerto public hospital.

Keywords : adherence level, anti retro viral therapy, HIV/AIDS

\section{PENDAHULUAN}

Kasus

HIV

(Human

Immunodeficiency Virus) / AIDS

(Acquired Immune Deficiency

Syndrome), sejak pertama kali ditemukan pada tahun 1987 sampai dengan Juni 2012 sudah tersebar di 378 (76\%) dari 498 kabupaten/kota di seluruh (33) provinsi di Indonesia. Provinsi pertama kali ditemukan adanya kasus HIV/AIDS adalah Provinsi Bali pada tahun 1987, sedangkan yang terakhir melaporkan adanya kasus HIV pada tahun 2011 adalah Provinsi Sulawesi Barat (Anonim, 2012). Kasus HIV/AIDS di Indonesia semakin meningkat, sejak tahun 1999 telah terjadi peningkatan jumlah Orang dengan HIV/AIDS (ODHA) pada sub populasi tertentu di beberapa provinsi yang memang mempunyai prevalensi HIV cukup tinggi.
Peningkatan ini terjadi pada kelompok orang berperilaku beresiko tinggi tertular HIV yaitu para pekerja seks komersial dan pengguna NAPZA (Narkotik, Alkohol, Psikotropika, dan Zat Adiktif lainnya) suntikan di 6 provinsi : DKI Jakarta, Papua, Riau, Bali, Jawa Barat, dan Jawa Timur (concentrated level of epidemic). Bila masalah ini tidak ditanggulangi segera, maka kemungkinan besar epidemik akan bergerak menjadi epidemik yang menyeluruh dan parah (generalized epidemic) (Anonim ${ }^{\mathrm{a}}$, 2011).

Meskipun AIDS belum bisa disembuhkan, namun infeksi ini dapat dikendalikan dengan pengobatan Anti Retro Viral (ARV). Dari Laporan Situasi Perkembangan HIV/AIDS di Indonesia sampai dengan September 2011 tercatat 
jumlah ODHA yang mendapatkan terapi ARV sebanyak 22.843 dari 33 provinsi dan $300 \mathrm{kab} / \mathrm{kota}$ (Anonim ${ }^{\mathrm{a}}$, 2011). Peningkatan jumlah kasus HIV yang signifikan dan semakin banyaknya penderita HIV yang berubah memasuki stadium AIDS saat sistem kekebalan tubuh menurun sehingga kadar CD4 kurang dari 200 sel/ $\mu 1$, kemungkinan disebabkan karena ketidakpatuhan dalam pengobatan ARV. Banyak ODHA yang sudah menjalani terapi tetapi masih belum mengerti secara jelas mengenai semua aspek pengobatannya, termasuk dampak dari kepatuhan, efek samping, dan kombinasi obat, atau bagaimana mendapatkan obat tersebut. Ada laporan bahwa banyak ODHA memakai obat tanpa mengikuti pedoman walaupun sudah mendapatkan pengarahan oleh dokter (Spiritia, 2009).

Kepatuhan pada pengobatan ARV telah diketahui sebagai komponen penting untuk mencapai keberhasilan suatu program terapi yang optimal. Penelitian tentang kepatuhan tersebut di negara maju menunjukkan bahwa tingkat kepatuhan yang tinggi berkaitan erat dengan perbaikan virologis maupun klinis (Anonim, 2007). Kepatuhan terhadap terapi merupakan hal yang kritis untuk mendapatkan kemanfaatan penuh dari terapi ARV termasuk memaksimalkan serta penekanan yang lama terhadap replikasi virus, mengurangi kerusakan sel-sel CD4, pencegahan resistensi virus, peningkatan kembali kekebalan tubuh, dan memperlambat perkembangan penyakit (Steel, et al, 2007). Disarankan kepada ODHA bahwa penting untuk memakai paling sedikit 95\% dosis ARV $(<3$ dosis tidak diminum dalam periode 30 hari pada dosis pengobatan dua kali sehari) dengan cara dan waktu yang tepat agar ARV memiliki kesempatan terbaik untuk mencapai dan mempertahankan penekanan terhadap HIV (Spritia, 2010).

Beberapa faktor penting yang menyebabkan ketidakpatuhan pengobatan HIV/AIDS antara lain regimen obat, efek samping, kesulitan dalam mendapatkan obat, mahalnya harga obat (Anonim, 2006), lupa memakai obat atau terlalu sibuk, takut statusnya terungkap, tidak memahami pengobatan, depresi/keputusasaan, dan tidak percaya dengan obatobatan (Carter, 2009).

Kementerian Kesehatan Republik Indonesia telah menetapkan sebanyak 278 rumah sakit rujukan ODHA (Surat Keputusan Menteri Kesehatan Republik Indonesia Nomor 780/MENKES/SK/IV/2011 tentang Penetapan Lanjutan Rumah Sakit Rujukan Bagi Orang dengan HIV/AIDS) yang tersebar di hampir semua provinsi di Indonesia. Di Provinsi Jawa Tengah, Rumah Sakit Umum Daerah Prof. Dr. Margono Soekarjoyang berlokasi di Kota Purwokerto merupakan salah satu 
rumah sakit rujukan ODHA di wilayah Banyumas.

Penelitian ini memiliki tujuan untuk menganalisis faktor-faktor yang mempengaruhi tingkat kepatuhan pengobatan ARV pada ODHA di RSUD Prof. Dr. Margono Soekarjo Purwokerto dan menganalisis seberapa besar pengaruh faktor-faktor yang mempengaruhi tingkat kepatuhan pengobatan ARV pada ODHA di RSUD Prof. Dr. Margono Soekarjo Purwokerto secara statistik.

\section{METODE PENELITIAN}

Penelitian ini merupakan penelitian non eksperimental dengan rancangan penelitian cross sectional, yaitu variabel yang diteliti dalam penelitian ini dikumpulkan dalam waktu yang bersamaan, untuk mengetahui faktor-faktor yang mempengaruhi tingkat kepatuhan pengobatan ARV pada ODHA di RSUD Prof. Dr. Margono Soekarjo Purwokerto.

Tingkat kepatuhan dalam menjalani terapi ARV pada ODHA diukur dengan kuesioner yang diadaptasi dari kombinasi antara AIDS Clinical Trials Group (ACTG) Adherence Questionnaire dan Morisky 8-Item Medication Adherence Questionnaire yang meliputi faktor pengetahuan, faktor keyakinan, faktor sarana, faktor jarak dan biaya, faktor dukungan sosial, faktor psikologis yang dialami pasien selama seminggu terakhir, faktor psikologis pasien yang dialami selama sebulan terakhir serta faktor efek samping obat yang dirasakan pasien.

\section{HASIL DAN PEMBAHASAN}

A. Tingkat Kepatuhan Responden

Pengukuran tingkat kepatuhan responden penelitian dilakukan dengan menggunakan menggunakan Morisky 8-Item Medication Adherence Questionnaire yang sudah banyak diaplikasikan dalam berbagai penelitian (Morisky, 1986). Selain itu, kuesioner ini relatif lebih mudah digunakan dibandingkan pengukuran kepatuhan terapi dengan metode lainnya. Penilaian tingkat kepatuhan menggunakan scoring untuk jawaban "Ya" diberi nilai 1 sedangkan untuk jawaban "Tidak" diberi nilai 0 . Interpretasi penilaian adherens adalah sebagai berikut (Morisky, 1986) :

$$
\begin{aligned}
& \text { Jika } 0 \text { poin }=\text { kepatuhan } \\
& \text { tinggi } \\
& \leq 2 \text { poin }=\text { kepatuhan } \\
& \quad \text { sedang } \\
& >2 \text { poin }=\text { kepatuhan } \\
& \quad \text { rendah }
\end{aligned}
$$

Responden di klinik VCT RSUD Prof. Dr. Margono Soekarjo Purwokerto yang berpartisipasi dalam penelitian ini mayoritas memiliki tingkat kepatuhan yang sedang terhadap terapi ARV yaitu dengan persentase $87 \%$. Hal ini merupakan pencapaian yang belum maksimal sehingga perlu 
ditingkatkan lagi. Mengingat kepatuhan terhadap terapi ARV sangat penting setidaknya mempunyai tingkat adherens $90-95 \%$ agar dapat mempertahankan penekanan replikasi virus HIV secara maksimal dan meningkatkan kekebalan tubuh ODHA sehingga meningkatkan kualitas hidup ODHA Karena dengan tingkat kepatuhan yang lebih rendah dapat mengakibatkan kegagalan virologis,

Tabel I. Tingkat Kepatuhan Responden

\begin{tabular}{ll}
\hline Kepatuhan & Responden \\
\hline Tinggi & $0(0 \%)$ \\
Sedang & $27(87 \%)$ \\
Rendah & $4(13 \%)$ \\
\hline
\end{tabular}

pengrusakan sistem imun, resisten, pilihan pengobatan masa mendatang terbatas, biaya meningkat, berkembangnya penyakit terlebih untuk HIV/AIDS sendiri yang dapat menurunkan kekebalan tubuh. Oleh karena itu, kepatuhan ODHA terhadap terapi antiretroviral harus selalu dipantau dan di evaluasi secara teratur serta didorong pada setiap kunjungan.

\section{B. Faktor-faktor mempengaruhi yang Kepatuhan Terapi Anti Retro Viral}

1. Faktor Pengetahuan

Tingkat pengetahuan sebagian besar responden penelitian
(21 orang) dikategorikan sedang, hal ini terkait dengan tingkat pendidikan responden penelitian yang relatif tinggi (SMU, Diploma dan Sarjana) (tersaji pada tabelII). Tingkat pengetahuan responden yang baik diharapkan bisa menjadi salah satu faktor pendorong dalam mematuhi jadwal pengobatan, dengan tingkat pengetahuan yang baik responden akan menghindari resiko kegagalan terapi serta mengupayakan keberhasilan terapi sebaik mungkin.

2. Faktor Keyakinan

Keyakinan terhadap terapi ARV pada sebagian besar responden penelitian (16 orang) dikategorikan tinggi (tersaji pada table III).

Tabel II. Pengetahuan Responden Penelitian

\begin{tabular}{ll}
\hline Kategori & Responden \\
\hline Tinggi & $0(0 \%)$ \\
Sedang & $21(70 \%)$ \\
Rendah & $10(30 \%)$ \\
\hline
\end{tabular}


Tabel III. Keyakinan Responden Penelitian

\begin{tabular}{ll}
\hline Kategori & Responden \\
\hline Tinggi & $16(52 \%)$ \\
Sedang & $15(48 \%)$ \\
Rendah & $0(0 \%)$ \\
\hline
\end{tabular}

Responden memahami pengobatan ARV secara keseluruhan, responden juga meyakini jika penggunaan obat yang tidak teratur akan menimbulkan resistensi akibatnya perkembangan penyakit yang diderita akan semakin memburuk. Keyakinan yang tinggi diharapkan responden bisa lebih mematuhi terapi ARV.

\section{Faktor Sarana}

Pendapat responden mengenai sarana terapi ARV di rumah sakit sebagian besar responden penelitian (25 orang) masih mengkategorikan tinggi (tersaji pada tabel IV). Responden sudah mendapatkan sarana/fasilitas pengobatan yang baik, mendapatkan obat mudah baik secara prosedur ataupun dari keterjangkauan harga, karena pengobatan ARV tidak dikenakan biaya serta responden berkesempatan penuh untuk berkonsultasi dengan dokter mengenai perkembangan penyakitnya. Ketersediaan sarana dan fasilitas terapi anti retroviral diharapkan bisa mendorong responden untuk mengupayakan keberhasilan terapinya dengan mematuhi pengobatan yang sudah dijadwalkan pihak rumah sakit.

4. Faktor Jarak dan Biaya

Pendapat responden mengenai jarak dan biaya terapi ARV sebagian besar responden penelitian mengkategorikan tinggi (12 orang) dan sedang (12 orang) (tersaji pada tabel V). Dari segi biaya, pasien HIV/AIDS tidak dikenakan biaya, pengobatan adalah gratis sehingga pasien tidak terbebani soal biaya.

Tabel IV. Sarana Terapi Antiretroviral

\begin{tabular}{ll}
\hline Kategori & Responden \\
\hline Tinggi & $25(80 \%)$ \\
Sedang & $6(20 \%)$ \\
Rendah & $0(0 \%)$ \\
\hline
\end{tabular}

Tabel V. Jarak dan Biaya Terapi Antiretroviral

\begin{tabular}{ll}
\hline Kategori & Responden \\
\hline Tinggi & $12(39 \%)$ \\
Sedang & $12(39 \%)$ \\
Rendah & $7(22 \%)$ \\
\hline
\end{tabular}


Sedangkan jarak tempuh dari tempat tinggal responden ke rumah sakit berbeda-beda, karena responden bertempat tinggal tersebar, tidak hanya di wilayah Kota Purwokerto tetapi ada juga yang berasal dari luar Kota Purwokerto. Meskipun jarak tempuh menuju rumah sakit berbeda beda diharapkan responden tetap bisa mematuhi jadwal pengobatannya, karena biaya pengobatannya sendiri sudah tidak lagi menjadi kendala bagi responden untuk memperoleh pengobatan ARV.

C. Faktor Dukungan Sosial

Sebagian besar responden penelitian (27 orang) mengkategorikan dukungan sosial dalam kategori sedang dan responden lain (4 orang) mengkategorikan tinggi (tersaji pada table VI). Hal ini menunjukkan

dirinya depresi. Responden dengan kondisi psikologis yang baik tentunya akan dapat menjalani pengobatan dengan baik, salah bahwa secara sosial responden penelitian sudah mendapatkan dukungan yang baik dari lingkungan sekitarnya. Dukungan moriil dari orang-orang yang berada di sekitar responden bisa menjadi penyemangat dalam menjalankan rutinitas pengobatan.

D. Faktor Kondisi Psikologis Sebulan Terakhir

Sebagian besar responden penelitian (27 orang) mengkategorikan kondisi psikologisnya dalam sebulan terakhir dalam kategori baik dan responden lain (2 orang) mengkategorikan sedang (tersaji pada tableVII). Hal ini menunjukkan bahwa responden memiliki kondisi psikologis yang relatif baik. Responden dapat mengkontrol dirinya dari perasaan perasaan negatif yang bisa membuat satunya dengan cara mematuhi jadwal terapi

Tabel VI. Dukungan Sosial terhadap Responden Penelitian

\begin{tabular}{ll}
\hline Kategori & Responden \\
\hline Tinggi & $4(13 \%)$ \\
Sedang & $27(87 \%)$ \\
Rendah & $0(0 \%)$ \\
\hline
\end{tabular}

Tabel VII. Kondisi Psikologis Responden Sebulan Terakhir

\begin{tabular}{ll}
\hline Kategori & Responden \\
\hline Baik & $27(87 \%)$ \\
Sedang & $4(13 \%)$ \\
Buruk & $0(0 \%)$
\end{tabular}


E. Faktor Kondisi Psikologis

Seminggu Terakhir

Sebagian besar responden penelitian (28 orang) mengkategorikan kondisi psikologisnya dalam seminggu terakhir dalam kategori baik dan responden lain (3 orang) mengkategorikan sedang (tersaji pada table VIII). Sama halnya dengan kondisi psikologis yang dirasakan sebulan terakhir. Ada peningkatan jumlah responden dalam kategori baik yang menandakan bahwa responden dalam seminggu terakhir

sudah bisa mengontrol dirinya jauh lebih baik daripada sebulan terakhir yang sudah dirasakan.
F. Faktor Efek Samping Obat

Sebagian besar $\quad \begin{array}{r}\text { responden } \\ \text { orang) }\end{array}$
penelitian (29 kondisinya dalam
mengkategorikan kain (
kategori baik dan responden lain
orang) mengkategorikan sedang
(tersaji pada table IX). Hal ini
menunjukkan bahwa efek samping
obat ARV yang dirasakan oleh
responden masih tergolong ringan
dan masih dapat diatasi oleh
responden. Selama efek samping
obat masih dapat diatasi pasien
seharusnya hal tersebut tidak
menjadi penghambat responde untuk
tetap patuh terhadap jadwal
terapinya.

Tabel VIII. Kondisi Psikologis Responden Seminggu Terakhir

\begin{tabular}{ll}
\hline Kategori & Responden \\
\hline Baik & $28(90 \%)$ \\
Sedang & $3(10 \%)$ \\
Buruk & $0(0 \%)$ \\
\hline
\end{tabular}

Tabel IX. Kondisi Psikologis Responden Seminggu Terakhir

\begin{tabular}{ll}
\hline Kategori & Responden \\
\hline Baik & $29(96 \%)$ \\
Sedang & $2(4 \%)$ \\
Buruk & $0(0 \%)$ \\
\hline
\end{tabular}

Tabel X. Hasil Uji Korelasi Spearman Rank atau Kendall's

\begin{tabular}{lll}
\hline Faktor yang mempengaruhi Kepatuhan & \multicolumn{2}{l}{ Nilai signifikansi } \\
& Kendall's & Spearman Rank \\
\hline Pengetahuan & 0,666 & 0,674 \\
Keyakinan & 0,720 & 0,727 \\
Sarana & 0,113 & 0,114 \\
Jarak dan biaya & 0,372 & 0,364 \\
Dukungan sosial & 0,256 & 0,263 \\
Kondisi psikologis sebulan terakhir & $0,025^{*}$ & $0,023^{*}$ \\
Kondisi psikologis seminggu terakhir & $0,004^{*}$ & $0,002^{*}$ \\
Efek samping obat & $0,014^{*}$ & $0,011^{*}$ \\
\hline \multicolumn{2}{c}{$*$ korelasi signifikan pada tingkat kepercayaan 0,05}
\end{tabular}


Tabel XI. Nilai Koefisien Korelasi Spearman Rank atau Kendall's

\begin{tabular}{lll}
\hline Faktor yang mempengaruhi Kepatuhan & Spearman's rho & Kendall's tau \\
\hline Kondisi Psikologi Seminggu Terakhir & 0,408 & 0,392 \\
Kondisi Psikologis Sebulan Terakhir & 0,524 & 0,504 \\
Efek Samping Obat & 0,449 & 0,432 \\
\hline
\end{tabular}

G. Analisis Faktor-faktor yang mempengaruhi Tingkat Kepatuhan Terapi Anti Retro Viral

Hasil uji korelasi Spearman Rank atau Kendall's memperlihatkan bahwa tidak semua faktor memiliki nilai sigifikansi $<0,05$ (tersaji pada table X).

Hanya faktor kondisi psikologis seminggu terakhir, faktor kondisi psikologis sebulan terakhir dan faktor efek samping obat yang dinyatakan signifikan. Artinya bahwa ketiga faktor tersebut memiliki pengaruh terhadap tingkat kepatuhan terapi ARV. Faktor-faktor yang lain (faktor pengetahuan, faktor keyakinan, faktor sarana, faktor jarak dan biaya, faktor dukungan sosial) dinyatakan tidak signifikan, maka artinya data yang dikumpulkan tidak berhasil membuktikan keterkaitan antara faktor-faktor tersebut terhadap kepatuhan terapi, akan tetapi bukan berarti bahwa faktor-faktor tersebut tidak berpengaruh terhadap kepatuhan terapi. Dengan kata lain, sampel yang diperoleh tidak bisa digeneralisasi terhadap populasi penelitian. Adapun nilai koefisien korelasi yang diperoleh adalah sebagai berikut :
Koefisien korelasi digunakan untuk melihat keeratan hubungan antara faktor-faktor tersebut di atas dengan tingkat kepatuhan terapi anti retroviral. Dengan demikian, dari penelitian ini dapat disimpulkan bahwa kondisi psikologis yang dialami responden mempengaruhi tingkat kepatuhan terapi ARV. Hal ini sejalan dengan penelitian yang telah dilakukan oleh Fiona di London pada Maret 2010 bahwa kondisi kesehatan pasien yang merupakan gejala fisik dan psikologis terkait HIV dapat mempengaruhi kepatuhan pengobatan ARV. Selain itu, faktor efek samping obat memiliki pengaruh terhadap kepatuhan terapi ARV, hal ini sejalan dengan penelitian yang telah dilakukan oleh Margaret di California pada tahun 2000 bahwa faktor regimen obat (jumlah tablet, frekuensi pemakaian), ukuran tablet, serta efek samping obat dapat mempengaruhi kepatuhan pengobatan ARV.

\section{KESIMPULAN}

Hasil penelitian menyatakan bahwa faktor kondisi psikologis seminggu terakhir, faktor kondisi psikologis sebulan terakhir dan faktor efek samping obat 
mempengaruhi secara signifikan terhadap tingkat kepatuhan terapi ARV pada ODHA di RSUD Prof. Dr. Margono Soekarjo Purwokerto. Hasil uji hipotesis Spearman Rank menyatakan besarnya pengaruh faktor kondisi psikologis seminggu terakhir terhadap kepatuhan terapi ARV pada ODHA di RSUD Prof. Dr. Margono Soekarjo Purwokerto secara statistik dinyatakan dengan $\mathrm{p}$ $=0,408$, besarnya pengaruh faktor kondisi psikologis sebulan terakhir terhadap kepatuhan terapi ARV pada ODHA di RSUD Prof. Dr. Margono Soekarjo Purwokerto secara statistik dinyatakan dengan $p$ 0,524 , besarnya pengaruh faktor efek samping obat terhadap kepatuhan terapi ARV pada ODHA di RSUD Prof. Dr. Margono Soekarjo Purwokerto secara statistik dinyatakan dengan $\mathrm{p}=0,449$

\section{DAFTAR PUSTAKA}

Anonim, 2011, Tatalaksana Klinis Infeksi HIV dan Terapi Antiretroviral pada orang Dewasa. Depkes RI, Jakarta.

Anonim, 2012, Pengendalian HIVAIDS di Indonesia.
Arikunto, S., 2002, Prosedur Penelitian, Suatu Pendekatan Praktek. Jakarta: PT Rin eka Cipta.

Carter, M., 2009, Depresi pada Awal Berarti Kurang Patuh pada ARV. (http://aidsmap.com, diakses tanggal 16 Oktober 2012).

Fiona, 2010, Physical and Psychological Symptoms Predict HIV Viral Load Rebound. Department of Infection and Population Health, University College London Medical School, London.

Jogiyanto, H.M., 2008 Metodologi Penelitian Sistem Informasi C.V Andi ,Yogyakarta.

Margaret, A., 2000, Factors Affecting Adherence to Antiretroviral Therapy. School of Medicine, University of California, San Fransisco.

Morisky, D.E., Green, L.W., Levine, D.M., 1986, Concurrent and predictive validity of a self reported measure of medication adherence, Med Care.

Spiritia, 2009, Pelatihan Pendidik Pengobatan, [pdf], (http://spiritia.or.id, diakses tanggal 16 Oktober 2012)

Spiritiam, 2010, Kepatuhan Terhadap terapi. (http://spiritia.or.id, diakses tanggal 18 Oktober 2012). 